\title{
A study to evaluate the keratoanalyzer in success of penetrating kertoplasty
}

\author{
Kundan Malhotra1, Gunjan Tank ${ }^{2, *}$, Kunjan Patel ${ }^{3}$, Mansi Patel ${ }^{4}$, Devyani Vaghela ${ }^{5}$ \\ ${ }^{\mathbf{1}}$ Senior Resident, C H Nagri Eye Hospital, Ahmedabad, Gujarat, ${ }^{\mathbf{2}}$ Assistant Professor, ${ }^{\mathbf{3}}$ Associate Professor, ${ }^{\mathbf{4}, 5}$ Resident, Dept. of \\ Ophthalmology, ${ }^{3}$ Government Medical College, Civil Hospital, Surat, Gujarat, ${ }^{2,4,5} \mathrm{M} \&$ J Institute of Ophthalmology, BJ Medical \\ College, Ahmedabad, Gujarat, India
}

\section{*Corresponding Author: Gunjan Tank}

Email: gunjanvalu@yahoo.com

\begin{abstract}
Aims: To evaluate donor cornea by using eye bank specular microscope and evaluate outcome of keratolplasty according to the graft condition.

Materials and Methods: This was a prospective study of 30 patients who undergone keratoplasty. Donor cornea was evaluated by slit lamp biomicroscopy and after preservation in MK media, evaluated using eye bank specular microscope. Final decision of transplantation was made on grading of specular microscopy. All patients undergone penetrating keratoplasty and post-operative outcome was measured.

Results: In our study majority of donors were in age group of 21-40 years. Endothelial cell count of $>3000$ cells $/ \mathrm{mm}^{2}$ was observed in $60 \%$ cases, while $2500-3000$ cells $/ \mathrm{mm}^{2}$ in $26.67 \%$ cases. The reason for penetrating keratoplasty were corneal opacity or scarring (40\%), PBK (23.33\%), acute infective keratitis (13.33\%), regraft due to graft failure (10\%), ABK (10\%) and corneal dystrophy (3.33\%). Postoperative clear graft was seen in $60 \%$ cases while cloudy in $20 \%$ and opaque in $20 \%$ cases. It was observed that large number of recipients (46.66\%) had post-operative visual acuity more than $6 / 60$.

Conclusions: Though tissue utilization can be optimized with the use of eye bank specular analyzer, final outcome depends on multiple factors. Few tissues of older age can be utilized if having good endothelial count.
\end{abstract}

Keywords: Corneal blindness, Eye bank specular analyzer, Keratoplasty.

\section{Introduction}

Corneal pathology resulting in corneal scarring is a common cause of preventable and treatable blindness in children $\&$ adults. In India, there are approximately 6.8 million people who have corneal blindness with vision less than $6 / 60$ in at least one eye, and of these, about 1 million have bilateral corneal blindness. ${ }^{1,2}$ In India, only 65,137 corneas were collected in the year 2016-17 which is far lesser than the requirement $(2,00,000){ }^{3}$ This clearly shows that there is a huge gap between demand and supply of donor corneal tissues in India. Though good information about the eye can be gathered through a slit-lamp examination, eye bank keratoanalyzer is useful instrument to access the corneal endothelium. This instrument gives us exact detail of the number of endothelial cells, its condition, morphological pattern thus allowing objective assessment of the donor's endothelium and helping reach final decision on whether to proceed with transplantation or not.

\section{Materials and Methods}

The present study is a prospective study of 30 patients (30 recipient eyes) of corneal diseases, in whom cornea was transplanted from 30 donor eyes, which was evaluated on slit lamp \& eye bank keratoanalyzer. All the patients were postoperatively examined for graft survival. All the patients enrolled in study were evaluated over a period of 27 months. Tissues with systemic history not available, cause of death not known, blood sample not available, having history of transmissible diseases and positive serological test, tissues in which specular examination was not possible or with poor clinical grading where corneo-scleral button was not excised were excluded from study.

30 eyeballs initially moist chamber preserved were assessed by slit lamp bio-microscopy. Epithelial defects, exposure keratitis, corneal scars, epithelial and stromal edema, stromal opacities, descemet membrane folds, quality of endothelium, anterior chamber details, iris, pupil and lens status were studied. A clinical grade ranging from excellent to poor was assigned (Table 1). ${ }^{4,5}$ With aseptic precautions, full thickness corneoscleral button was excised from the eyeball and preserved in McCarey-Kaufman (M-K) medium. The qualitative and quantitative endothelial cell analysis with centre method was done by eye bank kerato analyzer. Endothelial cell study was done. Final grading and subsequent utilization of tissues for various transplant surgeries was then analyzed with regard to the influence of age of donor, death to enucleation time, death to preservation time and lens status of donor eye.

Through preoperative evaluation of recipient was done including ocular as well as systemic condition. Penetrating keratoplasty was performed following the ethical guidelines for biomedical research on human subjects issued by the Indian Council of Medical Research in 2000. The Institutional Ethical Committee had cleared the project. All the patients had given their informed consent. All PKs were performed under local or general anesthesia. Trephination of recipient \& donor cornea was done with disposable corneal trephine. Corneal button was excised with corneal scissors. The 
recipient corneal button \& donor corneal rim was sent for microbiology and histopathology for examination to confirm the diagnosis. Peripheral iridectomy was performed. Donor button oversized by $0.25 / 0.5 \mathrm{~mm}$ and punched from endothelial side up by corneal punch was taken. Donor cornea was sutured to the host with 10.0 ethicon polyamide nonabsorbable monofilament sutures with interrupted suture technique in all recipient patients. An anterior vitrectomy was performed in complicated cases if necessary. Postoperatively, the eyes were patched and corticosteroids were administered topically. Topical steroid drops were instilled in the operated eye four times to 1 hourly instilled in a day initially and the frequency was increased or decreased depending on the degree of inflammation. Gradually steroid was tapered over a period of one year. Topical antibiotics, antifungal \&/or fortified drops were continued till there was no suspicion of infection. Short-acting cycloplegic (cyclopentolate 1\%) was instilled till iritis subsided. Topical antiglaucoma medication and lubricants were given in the initial period. 3 doses of intravenous methyl prednisolone (pulse regimen) were given for 3 days in cases of graft rejection. The patients were evaluated on first day, first week, and fifteenth day and then on first, third and six months \& one year postoperatively in the same manner as the preoperative assessment mentioned above. The results were statistically analyzed by use of mean, standard deviation $\&$ test of association- chi square test.

\section{Results and Discussion}

Age wise category of donor cornea was 5-20 years (16.66\%), 21-40 years (50\%), 41-60 years (10\%), 61-80 years $(23.33 \%)$ while majority of cases of recipient cornea belonged to $51-70$ years $(46.66 \%)$ and few of $31-40$ years $(6.67 \%)$ years. It was observed that majority of donors were in age group of 21-40 years. Amongst donor, $70 \%$ were males and $30 \%$ were females while in case of recipient, $69.4 \%$ were males and $30.6 \%$ were females. Death to enucleation time was 0.5-6 hours. In study by Mittal et al, ${ }^{6}$ post-operative clear graft was seen in $83.33 \%$ cases when death to enucleation interval was less than 6 hours, while it was only $40 \%$ when that interval was more than 6 hours. Death to preservation interval was $1.20-19$ hours in which mean \pm SD was $5.10 \pm 3.48$ hours. Epithelial defect on donor graft was seen in $36.67 \%$ cases while intact epithelium was seen in $63.33 \%$ cases. Excellent grading according to slit lamp findings was found in $33.3 \%$ cases, very good in $53.33 \%$ cases while good in $13.33 \%$ cases. In tissues having excellent grading, $90 \%$ donor tissue was of younger age group $(<40$ years) while only $10 \%$ donor tissue was of more than 40 years of age. In tissues of very good grading, $68.75 \%$ donor tissue were $<40$ years and $31.25 \%$ tissue were having age $>40$ years. Good grading tissue was seen in only older ( $>40$ years) donors. Endothelial cell count of
$>3000$ cells $/ \mathrm{mm}^{2}$ was observed in $60 \%$ cases, while $2500-3000$ cells $/ \mathrm{mm}^{2}$ in $26.67 \%$ cases, $2000-2500$ cells $/ \mathrm{mm}^{2} 6.67 \%$ and $\leq 2000$ cells $/ \mathrm{mm}^{2}$ in $6.67 \%$ donor tissue. $77.78 \%$ donor tissues of $<40$ years age group had endothelial cell count more than 3000 cells $/ \mathrm{mm} 2$, while the same was seen in $22.22 \%$ donor tissues more than 40 years of age (Fig. 1). Endothelial cell count more than 2500 cells/ $\mathrm{mm}^{2}$ was seen in $13.33 \%$ donor tissue of age more than 60 years, this upgraded such tissue for use of keratoplasty. In study by Jadeja et al, ${ }^{7}$ they have observed that $25 \%$ tissues from donor more than 60 years have endothelial count more than 2500 cell/ $\mathrm{mm}^{2}$. Thus with use of eye bank keratoanalyser, tissue utilization can be improved as otherwise tissue of older age are considered to have less endothelial count and underrated.

Prognostic category (Table 2) of $0+$ was seen in $6.67 \%$ cases, $1+\mathrm{A}$ in $3.33 \%$ cases, $1+\mathrm{B}$ in $10 \%$ cases, $2+$ in $36.67 \%$ cases, $3+$ in $26.67 \%$ cases, $4+$ in $13.33 \%$ cases and $5+$ in $3.33 \%$ cases. $^{8}$ The reasons for keratoplasty were corneal opacity or scarring (40\%), PBK $(23.33 \%)$, acute infective keratitis $(13.33 \%)$, regraft due to graft failure $(10 \%), \mathrm{ABK}(10 \%)$ and corneal dystrophy $(3.33 \%)$. It was observed that corneal opacity/scarring and PBK were the leading cause of corneal blindness so common indication for penetrating keratoplasty which was comparable with Dandona et al. ${ }^{9}$ Corneal scarring because of infectious keratitis was common in Indian scenario due to agricultural and industrial exposure. PBK incidence has also increased due to large number of cataract surgeries being done with IOL implantation. Postoperative clear graft was seen in $60 \%$ cases while cloudy in $20 \%$ and opaque in $20 \%$ cases. While in study of Mittal et $\mathrm{al},{ }^{6}$ postoperative clear graft was seen in $83.3 \%$, cloudy in $8.3 \%$ and opaque in $8.3 \%$ cases. In their study few tissues were transplanted which was retrieved more than 6 hours after death which we have not compared as in our study death to enucleation time was $0.5-6$ hours. It indicates that early enucleation as well as preservation of donor tissue improves post-operative graft outcomes even after one year follow up. It was observed that prognostic category of $0+$ to $2+$, clear graft was seen in $65.20 \%$ and cloudy/opaque graft in $34.78 \%$. We found strong association between recipient prognostic category of cornea and recipient graft outcome $(\mathrm{P}$ value- $0.040<0.05 \%$ ). With the graft size of 7 to 7.50 $\mathrm{mm}$, post-operative graft outcome was clear graft (72\%), cloudy $(20 \%)$ \& opaque $(8 \%)$, while $80 \%$ opaque \& $20 \%$ cloudy postoperative graft outcome was found in the graft size of $8 \mathrm{~mm}$ in which $\mathrm{p}$ value was significant. All patients had pre-operative visual acuity less than $3 / 60$. Postoperative visual acuity of $<1 / 60$ was seen in $26.67 \%, 1 / 60$ to $<3 / 60$ in $6.67 \%, 3 / 60$ to $<6 / 60$ in $20 \%, 6 / 60$ to $<6 / 18$ in $36.67 \%$ patients and $6 / 18$ to $6 / 6$ in $10 \%$ patients (Table 3 ). It was observed that large number of recipients $(46.66 \%)$ had post-operative visual acuity more than $6 / 60$ which was comparable 
with Yorston et al. ${ }^{10}$ Poor visual outcome (26.67\%) i.e. $<1 / 60$ was due to graft rejection, graft infection, graft failure, secondary glaucoma and corneal edema. Patients who received donor tissue with endothelial cell count $>2500$ cells $/ \mathrm{mm}^{2}$, postoperative best corrected visual acuity was $3 / 60$ To $6 / 6$ in $69.23 \%$ and $<3 / 60$ to
No PL in $30.77 \%$ cases while it was $50 \%$ each in whom the donor endothelial cell count was $<2500$ cells $/ \mathrm{mm}^{2}$. Visual acuity improvement in the corneal opacity was $75 \%$ and in PBK was $85.71 \%$, while no improvement in acute infective keratitis, graft failure and regraft conditions.

Table 1: Donor corneal tissue evaluation criteria

\begin{tabular}{|c|c|}
\hline Grade & Description \\
\hline Excellent & $\begin{array}{l}\text { Endothelial cell count-3000 Cells } / \mathrm{mm}^{2} \text {, No epithelial defects, Crystal clear stroma, No arcus } \\
\text { senilis, No folds in descemet's membrane, Excellent endothelium-no defects }\end{array}$ \\
\hline Very good & $\begin{array}{l}\text { Endothelial cell count- } 2500 \text { To } 3000 \text { Cells } / \mathrm{mm}^{2} \text {, Slight epithelial haze/defects, Clear stroma, } \\
\text { Very slight arcus, Few light folds in descemet's membrane, Very good to excellent } \\
\text { endothelium-no defects }\end{array}$ \\
\hline Good & $\begin{array}{l}\text { Endothelial cell count-2000 To } 2500 \text { Cells } / \mathrm{mm}^{2} \text {, Moderate epithelial defects, Light to } \\
\text { moderate Cloudiness, Moderate arcus senilis }<2.5 \mathrm{~mm} \text {, Numerous but shallow folds in } \\
\text { descemet's membrane, Few vacuolated cells }\end{array}$ \\
\hline Fair & $\begin{array}{l}\text { Endothelial cell count-1500 To } 2000 \text { Cells } / \mathrm{mm}^{2} \text {, Obvious epithelial defects }>60 \% \text {, Moderate } \\
\text { to heavy stromal Cloudiness, Heavy arcus senilis }>2.5 \mathrm{~mm} \text {, Heavy folds-numerous, deep, } \\
\text { central, Fair to good to endothelium-Moderate endothelial defects, vacuolated cells, low cell } \\
\text { density }\end{array}$ \\
\hline Poor & $\begin{array}{l}\text { Endothelial cell count- Less than } 1500 \mathrm{Cells} / \mathrm{mm}^{2} \text {,Moderate vacuolated cells, Severe stromal } \\
\text { Cloudiness, Marked folds-heavy, numerous, central, Fair endothelium-Marked endothelial } \\
\text { defects, numerous central vacuolated cells, low cell density, Technical problems in removal }\end{array}$ \\
\hline
\end{tabular}

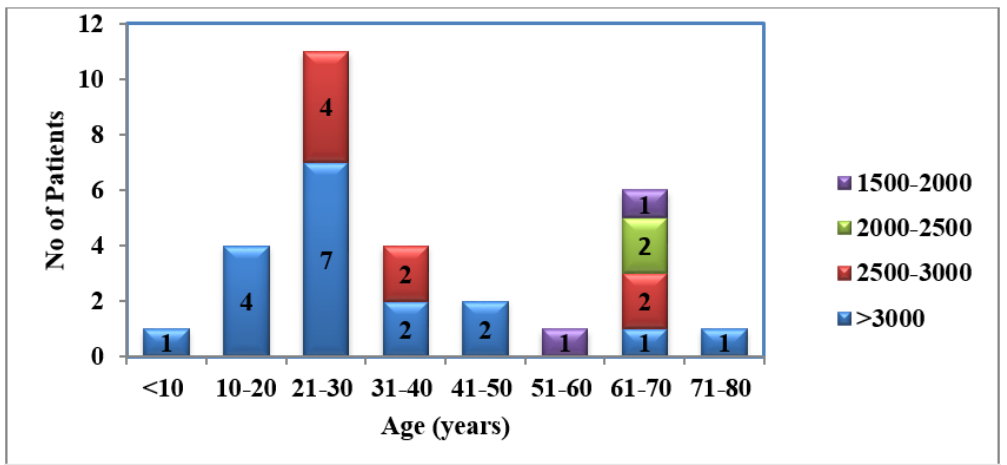

Fig. 1: Preoperative endothelial cell count in relation to age of donor

Table 2: Prognostic category of corneal disorder

\begin{tabular}{|l|l|}
\hline \multicolumn{1}{|c|}{ Category } & \multicolumn{1}{c|}{ Corneal condition } \\
\hline $0+$ & Corneal distortion or opacification free of scarring or neovascularisation \\
\hline $1+\mathrm{A}$ & Corneal scarring free of neovascularization \\
\hline $1+\mathrm{B}$ & Corneal scarring or edema free of neovascularisation, associated with intraocular diseases \\
\hline $2+$ & Corneal scarring with superficial neovascularisation \\
\hline $3+$ & Deep corneal scarring and neovascularisation free of intraocular disease \\
\hline $4+$ & Deep corneal scarring and neovascularisation accompanied by intraocular disease \\
\hline $5+$ & $\begin{array}{l}\text { Corneal ischemia, severe fibrovascular replacement of corneal and conjunctival tissue and } \\
\text { anterior chamber obliteration with non responsive glaucoma }\end{array}$ \\
\hline
\end{tabular}

Table 3: Improvement of visual acuity in different pathological conditions

\begin{tabular}{|c|c|c|c|c|c|c|c|c|c|c|}
\hline \multirow{2}{*}{$\begin{array}{l}\text { Pathological } \\
\text { Conditions }\end{array}$} & \multicolumn{2}{|c|}{ PL To $<1 / 60$} & \multicolumn{2}{|c|}{$1 / 60$ To $<3 / 60$} & \multicolumn{2}{|c|}{$3 / 60$ To $<6 / 60$} & \multicolumn{2}{|c|}{$6 / 60$ To $<6 / 18$} & \multicolumn{2}{|c|}{$6 / 18$ To $<6 / 6$} \\
\hline & Pre & Post & Pre & Post & Pre & Post & Pre & Post & Pre & Post \\
\hline PBK & $\begin{array}{c}7 \\
(100)\end{array}$ & & & & & $\begin{array}{c}2 \\
(28.57)\end{array}$ & & $\begin{array}{c}4 \\
(57.14)\end{array}$ & & $\begin{array}{c}1 \\
(14.29)\end{array}$ \\
\hline Corneal Opacity & $\begin{array}{c}10 \\
(83.33)\end{array}$ & $\begin{array}{c}2 \\
(16.67)\end{array}$ & $\begin{array}{c}2 \\
(16.67)\end{array}$ & $\begin{array}{c}1 \\
(8.33)\end{array}$ & & $\begin{array}{c}3 \\
(25)\end{array}$ & & $\begin{array}{c}5 \\
(41.67)\end{array}$ & & $\begin{array}{c}1 \\
(8.33)\end{array}$ \\
\hline
\end{tabular}




\begin{tabular}{|l|c|c|c|c|c|c|c|c|c|c|}
\hline $\begin{array}{l}\text { Acute Infective } \\
\text { Keratitis }\end{array}$ & $\begin{array}{c}4 \\
(100)\end{array}$ & $\begin{array}{c}4 \\
(100)\end{array}$ & & & & & & & & \\
\hline Graft Failure & $1(100)$ & $1(100)$ & & & & & & & & \\
\hline Regrafts & $2(100)$ & $1(50)$ & & $1(50)$ & & & & & & \\
\hline ABK & $3(100)$ & & & & & $\begin{array}{c}1 \\
(33.33)\end{array}$ & & $\begin{array}{c}2 \\
(66.67)\end{array}$ & & \\
\hline $\begin{array}{l}\text { Corneal } \\
\text { Dystrophy }\end{array}$ & & & $\begin{array}{c}1 \\
(100)\end{array}$ & & & & & & & 1 \\
\hline Total & & & & & & & & & & \\
\hline
\end{tabular}

\section{Conclusion}

Eye bank keratoanalyzer is very helpful tool before doing PK. The status of donor cornea was evaluated by tissue grading from excellent to poor with the help of slit-lamp examination, but after doing keratoanalysis, we definitely know whether donor tissue is of excellent or poor grade by endothelial cell count \& morphological features because more chances of graft failure or rejection occur in case of fair to poor grade tissue. Ultimate outcome depends upon multiple factors like condition of recipient cornea, graft size, systemic conditions etc.

\section{References}

1. Murthy GVS, Gupta SK, Bachani D. Current estimates of blindness in India. British Journal of

Ophthalmology. 2005;89:257-260.

2. Dandona R, Dandona L. Corneal blindness in a southern Indian population: Need for health promotion strategies. Br J Ophthalmol. 2003;87:133-141.

3. Kumar S, Shukla US, Agarwal P. Awareness and Knowledge on Eye Donation among Students at Bhopal. Natl J Community Med. 2012;3(4):685-689.

4. N. H. Patel, Sahil Bajaj, Amandeep Chawla, Saurabh Bothra. Cross-Sectional Study to Assess and Grade the Quality of Donor Corneal Material. Journal of Evolution of Medical and Dental Sciences. 2015;4(101)1659316595.

5. Saini JS, Reddy MK, Jain A K, Ravindra M S, Jhaveria S, Raghuram L. Perspectives in eye banking. Indian J Ophthalmol. 1996;44:47-5.

6. Mittal P C, Nahata M C, Moghe R. Factors affecting transparency of graft in keratoplasty. Indian $J$ Ophthalmol. 1983;31:674-679.

7. Jadeja JN, Patel BD, Shanbhag SS. The grave necessity to make eye bank specular microscopy mandatory in all eye banks in the subcontinent to improve utilization of scarce donor corneas. Indian J Ophthalmol. 2013;61:711-717.

8. Joshi SA, Jagdale SS, More PD, Deshpande M. Outcome of optical penetrating keratoplasties at a tertiary care eye institute in Western India. Indian J Ophthalmol. 2012;60:15-21.

9. Dandona L, Ragu K, Janarthanan M, Naduvilath T J, Shenoy R, Rao G N. Indications for penetrating keratoplasty in India. Indian J Ophthalmol. 1997;45:1638.

10. Yorston D, Wood M, Foster A Penetrating keratoplasty in Africa: graft survival and visual outcome. British Journal of Ophthalmology. 1996;80:890-894.
How to cite this article: Malhotra $\mathrm{K}$, Tank $\mathrm{G}$, Patel K, Patel M, Vaghela D. A study to evaluate the keratoanalyzer in success of penetrating kertoplasty. Indian $\mathrm{J}$ Clin Exp Ophthalmol. 2018;4(4):465-468. 